\title{
RESEARCHARTICLE
}

\section{COVID 19 PANDEMIC: ASSESSMENT OF KNOWLEDGE AND ATTITUDES IN BIOMEDICAL WASTE MANAGEMENT AMONG HEALTH CARE PROFESSIONALS IN TAMIL NADU}

\author{
Krithiga Pl, Sudharsana V22, Sribalaji R33, Snega $C^{4}$ \\ 1. Assistant Professor, Department of Civil Engineering, SBMS, Kongu Engineering College, Perundurai, Erode. India \\ 2,3,4. Students, Department of Civil Engineering, SBMS, Kongu Engineering College, Perundurai, Erode, India
}

Correspondence: krithipalanisamy@gmail.com

\begin{abstract}
Coronavirus, which was started provincially at Wuhan of China, has become a worldwide pandemic by affecting individuals of almost all the world. The developing pandemic of COVID-19 disease requires social distancing and individual cleanliness measures to secure general wellbeing. The aim of the present study is to evaluate the knowledge, attitude, practice and awareness of biomedical waste management in this pandemic situation among healthcare workers and medical students across Tamil Nadu.
\end{abstract}

A cross sectional questionnaire survey was prepared to evaluate the knowledge regarding waste management and waste handling techniques. The survey found that most of the hospitals (50\%) are using plastic containers for waste collection. Almost $79.7 \%$ of the respondents said they follow colour coding while disposing waste. When asked about exact category only few gave correct answers. Nearly $72.8 \%$ answered that they collect the Covid patient's wastes separately. As coronavirus is a contagious disease, each healthcare worker should be trained in safe handling of wastes. From this survey, it is clear that training about safe handling of waste is needed among workers. This survey will help government and healthcare providers to handle this Covid pandemic successfully and more effectively.

\section{KEYWORDS}

Biomedical, Waste Management, awareness, health hazards, COVID 19, Pandemic management

\section{INTRODUCTION}

The data from Central Pollution Control Board (CPCB), India indicates $28,468.85$ tonnes of bio-medical waste during COVID-19 for the last six months between June to November.[1] India is the second most populous country in the world after China. [2-3] Biomedical Waste is the waste produced during diagnosis, treatment or immunization of human or animal research activities. The waste management framework consists of characterisation, quantification, separation, storage, transfer and treatment methods. India has a strict rule on onsite segregation of biomedical waste for storing, transporting and disposing as essential standards of good biomedical waste management. This practice depends on the idea of 3R's 
reduce, recycle and reuse. The best Biomedical Waste Management aims at avoiding the generation of waste or recovering as much as possible rather than disposing. [4] A huge amount of biomedical waste generally arises from the isolation wards, quarantine centres and hospitals. New categories of biomedical waste has emerged after COVID19 outbreaks.[5]

Biomedical waste differs from the municipal waste as it creates more health hazards. Biomedical waste management rules were enacted in the year 2016 and amended in the 2018. They were provided by Ministry of environment, forest and climate change (MoEF) to implement the handling activities occurring in biomedical waste management. Due to the inconsistent knowledge in biomedical waste, India has faced severe crisis during COVID-19. They are in total 198 approved biomedical waste disposal facilities in the country and 28 are under construction. [6] Biomedical waste includes general waste, pathological waste, radioactive, chemical, and potentially infectious waste, sharps (includes needles, scalpel blades), pharmaceuticals and pressurized containers are the eight categories of medical waste categorized by world health organization.[7]

For segregation, the waste can be categorised into ten types. For easy segregation, later it was changed to four categories of yellow, red, white, and blue. The yellow indicates infected waste, whereas red category is marked as non-infected and recyclable. The sharps and tiny metallic items fall in the white category and lastly blue denotes the waste material that consists of glass. They are mainly five methods available for the treatment of medical wastes. They include chemical, treatment, mechanical, irradiation and biological process.[8] It is estimated that only $10-25 \%$ of biomedical waste are harmful and the remaining $75 \%-95 \%$ is harmless waste.[9] The hazardous waste is further classified into infectious waste and other hazardous waste. The infectious waste contains non sharps, sharps plastic disposable and liquid wastes while other hazardous wastes contain radioactive wastes, discarded glass, pressurized containers, chemical wastes, cytotoxic waste and incinerators ash.[5] Segregated waste was kept in open ventilated area and stored waste was transported to the biomedical disposal facilities.[10]

The hazardous biomedical wastes can result in different types of infections like respiratory, skin, upper and lower abdominal infections, as well as acquired immunodeficiency syndrome (AIDS), hepatitis, Congo-
Crimean, anthrax, brucellosis and tuberculosis.[11] For effective biomedical waste management source segregation is important in most of the healthcare establishment's segregations of medical waste was not done properly.[12] Improper disposal of infected face masks can make a significant risk for increasing COVID-19. [13] Most hospitals in India generate about one to two kg per bed per day except the tertiary care hospitals like AlIMS, Sher-I-Kashmir Institute of Medical Science (SKIMS) which produce increased amounts of waste. [14] After COVID-19 the waste generated increased significantly. The number of used facemasks and medical waste is increasing daily with the increase in number of COVID-19 cases. [15] In recent times, Delhi and Mumbai are most affected by corona virus in India. More than 40 sanitation workers have tested positive for the infection in Delhi and whereas in Mumbai 15 have lost their lives, 10 workers and 2 security monitors at the city's landfills, Kanjurmarg, have been contaminated with COVID-19 and recovered. [16] It is evident that private hospitals are producing more healthcare waste (Red and Yellow category of waste) than public hospitals in the given context. However, in blue category public hospitals are generating more waste than private ones. [17] Awareness programmes should not only be the objective for the doctors, nurses, paramedics; but also, the waste handlers. Proper training and demonstration of handling wastes should be given to waste handlers. [18] Literally, awareness about disposal of biomedical waste is very low among the lower age group people followed by male workers, supporting staff and labtechnicians. On the other hand, the doctors have good knowledge about rules and regulation regarding biomedical waste rules. Only few healthcare providers like medical students, health care professionals know the categorization of Biomedical Waste. [19] Teaching staff are also having more awareness in waste handling than nonteaching staff and other workers.[20] In this COVID-19 pandemic situation incineration is the best way to dispose of waste but, we should not forget the associated environmental problems [21] this causes. As indicated by the current circumstance, the pandemic is likely to extend past the year 2025. [22]

Effective biomedical waste management helps to reduce the environmental problems and safeguards public and healthcare workers from getting infected. Hence this present study aims to understand the knowledge, attitude and practice of biomedical waste management during this pandemic among medical students and healthcare workers across Tamil Nadu. 


\section{MATERIAL AND METHODS}

In this study sampling technique was used. This method was taken because in this pandemic, movement was severely restricted in India. It is not possible to take the questionnaire survey through direct contact with people. The study was cross sectional, accidental sampling and non-probability sampling method were carried out. For the initial pilot study, the sampling methods were seen to be very effective and positive in time saving and cost effective. A prevalence study was taken from April $1^{\text {st }}$ to $20^{\text {th }}, 2021$. We targeted people like doctors, medical students and faculty, nurses, health care professionals and some public people to know about their awareness level of corona virus. The semi structured questionnaire was prepared in concise form and reasonable English in Google form. The questionaries data were uploaded through Google Forms by distributing the link electronically. The question was structured and created for the people's knowledge on characteristics related to the handling and disposal of COVID-19 wastes and their consequences, identification of waste categories, hospital policies and awareness level on the COVID 19 virus. We disseminated the survey by social media, emails and mobile based networks like WhatsApp, Telegram. The participants showed the overwhelming responses where they passed to their friends all over Tamil Nadu. The questions were designed by standard guidelines and protocols as per WHO guidelines at the time. [23]

In total, 30 questions were included with 15 multiple choices and the remaining 15 were in YES/NO format. A total of 30 questionnaires were designed and distributed to medical college and hospitals treating COVID-19 patients across Tamil Nadu. We have received about 257 responses. Out of 257 responses, $39.69 \%(n=102)$ students, $27.63 \%(n=71)$ nurse followed by doctors and faculty were $18.68 \%(n=48)$ and 14 $\%(n=36)$ as described in Table 1.

TABLE 1: DEMOGRAPHIC INFORMATION OF RESPONDENTS

\begin{tabular}{|l|l|l|}
\hline VARIABLES & $\begin{array}{l}\text { PARTICIPANT } \\
(\mathbf{N})\end{array}$ & $\begin{array}{l}\text { PARTICIPANT } \\
\text { PERCENTAGE (\%) }\end{array}$ \\
\hline Doctors & 48 & $18.68 \%$ \\
\hline Nurses & 71 & $27.63 \%$ \\
\hline Faculty & 36 & $14 \%$ \\
\hline Students & 102 & $39.69 \%$ \\
\hline
\end{tabular}

\section{RESULTS}

The study presents the key findings from the total 257 respondents we divided the questions into four headings. The type of waste, ideas and waste generated during COVID 19 was shown in Figure 1, Figure 2 and Figure 3. The results of the survey were shown in the form of tables and charts, simultaneously the inference from the question has been discussed.

Table 2 is an extract of data from the survey and shows the awareness in the management of waste by the respondents

\section{TABLE 2 AWARENESS ABOUT WASTE MANAGEMENT}

\begin{tabular}{|l|l|l|}
\hline QUESTIONS & PARTICIPANTS(N) & $\begin{array}{l}\text { PARTICIPANTS IN } \\
\text { PERCENTAGE }\end{array}$ \\
\hline $\begin{array}{l}\text { 1.Do you follow the guidelines suggested by WHO for waste } \\
\text { management? }\end{array}$ & & \\
Yes & 193 & $75 \%$ \\
No & 64 & $25 \%$ \\
\hline
\end{tabular}




\begin{tabular}{|c|c|c|}
\hline $\begin{array}{l}\text { 2.After COVID } 19 \text { there is massive increase in Biomedical } \\
\text { waste production. } \\
\text { Agree } \\
\text { Disagree }\end{array}$ & $\begin{array}{l}241 \\
16\end{array}$ & $\begin{array}{l}93.8 \% \\
6.2 \%\end{array}$ \\
\hline $\begin{array}{l}\text { 3.Whether COVID } 19 \text { infected waste is mixed with non- } \\
\text { infected waste in your institution/hospital? } \\
\text { Yes } \\
\text { No } \\
\text { May be }\end{array}$ & $\begin{array}{l}201 \\
28 \\
28\end{array}$ & $\begin{array}{l}78.2 \% \\
10.9 \% \\
10.9 \%\end{array}$ \\
\hline $\begin{array}{l}\text { 4.How long do you store waste before treatment/disposal? } \\
\text { Less than } 24 \text { hours } \\
\text { More than } 24 \text { hours } \\
48 \text { hours } \\
\text { More than } 48 \text { hours }\end{array}$ & $\begin{array}{l}109 \\
60 \\
48 \\
40\end{array}$ & $\begin{array}{l}42.2 \% \\
23.4 \% \\
18.8 \% \\
15.6 \%\end{array}$ \\
\hline $\begin{array}{l}\text { 5.Types of containers used for waste collection } \\
\text { Plastic containers } \\
\text { Metal containers } \\
\text { Biohazard bags } \\
\text { Sharp bins }\end{array}$ & $\begin{array}{l}129 \\
56 \\
72 \\
0\end{array}$ & $\begin{array}{l}50 \% \\
21.9 \% \\
28.1 \% \\
0 \%\end{array}$ \\
\hline $\begin{array}{l}\text { 6. Whether anybody affected by COVID } 19 \text { while handling } \\
\text { wastes? } \\
\text { Yes } \\
\text { No } \\
\text { May be }\end{array}$ & $\begin{array}{l}44 \\
169 \\
44\end{array}$ & $\begin{array}{l}17.2 \% \\
65.6 \% \\
17.2 \%\end{array}$ \\
\hline $\begin{array}{l}\text { 7.Do you aware of biomedical waste rules and regulations } \\
\text { followed in India? } \\
\text { Yes } \\
\text { No } \\
\text { Know little bit }\end{array}$ & $\begin{array}{l}104 \\
44 \\
109\end{array}$ & $\begin{array}{l}40.6 \% \\
17.2 \% \\
42.2 \%\end{array}$ \\
\hline $\begin{array}{l}\text { 8.Do you have separate bins for collecting COVID patient } \\
\text { wastes? } \\
\text { Yes } \\
\text { No }\end{array}$ & $\begin{array}{l}177 \\
80\end{array}$ & $\begin{array}{l}68.8 \% \\
31.2 \%\end{array}$ \\
\hline $\begin{array}{l}\text { 9.Could staffs be trained regarding collection of COVID } \\
\text { patient's wastes? } \\
\text { Yes } \\
\text { No } \\
\text { May be }\end{array}$ & $\begin{array}{l}161 \\
44 \\
52\end{array}$ & $\begin{array}{l}62.5 \% \\
17.2 \% \\
20.3 \%\end{array}$ \\
\hline $\begin{array}{l}\text { 10.Improper waste management cause various health } \\
\text { hazards } \\
\text { True } \\
\text { False }\end{array}$ & $\begin{array}{l}229 \\
28\end{array}$ & $\begin{array}{l}89.1 \% \\
10.9 \%\end{array}$ \\
\hline $\begin{array}{l}\text { 11.Is it necessary to improve the waste management } \\
\text { technique during CoVID19 pandemic? } \\
\text { Yes } \\
\text { No } \\
\text { May be }\end{array}$ & $\begin{array}{l}205 \\
32 \\
20\end{array}$ & $\begin{array}{l}79.7 \% \\
12.5 \% \\
7.8 \%\end{array}$ \\
\hline
\end{tabular}




\begin{tabular}{|c|c|c|}
\hline $\begin{array}{l}\text { 12.Do you follow color coding while disposing wastes? } \\
\text { Yes } \\
\text { No } \\
\text { Never noticed }\end{array}$ & $\begin{array}{l}205 \\
24 \\
28\end{array}$ & $\begin{array}{l}79.7 \% \\
9.4 \% \\
10.9 \%\end{array}$ \\
\hline $\begin{array}{l}\text { 13.Which disposal technique is followed by your } \\
\text { hospital/institution? } \\
\text { Taken to Municipal landfill } \\
\text { Buried at hospital ground } \\
\text { Incineration }\end{array}$ & $\begin{array}{l}109 \\
44 \\
104\end{array}$ & $\begin{array}{l}42.2 \% \\
17.2 \% \\
40.6 \%\end{array}$ \\
\hline $\begin{array}{l}\text { 14.Is there any biomedical waste disposal policy in you } \\
\text { hospital/Institution? } \\
\text { Yes } \\
\text { No } \\
\text { Maybe }\end{array}$ & $\begin{array}{l}185 \\
36 \\
36\end{array}$ & $\begin{array}{l}71.8 \% \\
14.1 \% \\
14.1 \%\end{array}$ \\
\hline $\begin{array}{l}\text { 15. Whether maintaining Biomedical waste record is } \\
\text { mandatory in your hospital/clinic? } \\
\text { Yes } \\
\text { No }\end{array}$ & $\begin{array}{l}181 \\
76\end{array}$ & $\begin{array}{l}70.3 \% \\
29.7 \%\end{array}$ \\
\hline $\begin{array}{l}\text { 16.What type of waste you often see during COVID-19 } \\
\text { pandemic? } \\
\text { Masks } \\
\text { Needles } \\
\text { Gloves } \\
\text { Bandages }\end{array}$ & $\begin{array}{l}213 \\
20 \\
20 \\
4\end{array}$ & $\begin{array}{l}82.8 \% \\
7.8 \% \\
7.8 \% \\
1.6 \%\end{array}$ \\
\hline $\begin{array}{l}\text { 17. How long is the disposal site from your } \\
\text { hospital/institution? } \\
\text { Nearer } \\
\text { Far apart }\end{array}$ & $\begin{array}{l}112 \\
145\end{array}$ & $\begin{array}{l}43.8 \% \\
56.2 \%\end{array}$ \\
\hline $\begin{array}{l}\text { 18. What type of laboratory facilities do you have? } \\
\text { Clinical/biomedical } \\
\text { R\&D } \\
\text { Animal }\end{array}$ & $\begin{array}{l}175 \\
40 \\
42\end{array}$ & $\begin{array}{l}68 \% \\
15.6 \% \\
16.4 \%\end{array}$ \\
\hline $\begin{array}{l}\text { 19. Which color bin is used to dispose glassware and } \\
\text { metallic body implants? } \\
\text { Blue bins } \\
\text { White bins } \\
\text { Yellow bins } \\
\text { Don't know }\end{array}$ & $\begin{array}{l}100 \\
72 \\
32 \\
53\end{array}$ & $\begin{array}{l}39.1 \% \\
28.1 \% \\
12.5 \% \\
20.3 \%\end{array}$ \\
\hline $\begin{array}{l}\text { 20.Pathalogical wastes are disposed in? } \\
\text { Blue bins } \\
\text { Red bins } \\
\text { Yellow bins } \\
\text { Don't know }\end{array}$ & $\begin{array}{l}44 \\
41 \\
100 \\
72\end{array}$ & $\begin{array}{l}17.2 \% \\
15.6 \% \\
39.1 \% \\
28.1 \%\end{array}$ \\
\hline $\begin{array}{l}\text { 21.Contaminated wastes(recyclable) are disposed in? } \\
\text { Blue bins } \\
\text { Red bins } \\
\text { Yellow bins } \\
\text { Don't know }\end{array}$ & $\begin{array}{l}36 \\
81 \\
72 \\
68\end{array}$ & $\begin{array}{l}14 \% \\
31.3 \% \\
28.1 \% \\
26.6 \%\end{array}$ \\
\hline
\end{tabular}




\begin{tabular}{|c|c|c|}
\hline $\begin{array}{l}\text { 22.Did you notice any charts regarding waste disposal } \\
\text { displayed near dust bins? } \\
\text { Yes } \\
\text { No }\end{array}$ & $\begin{array}{l}161 \\
96\end{array}$ & $\begin{array}{l}62.5 \% \\
37.5 \%\end{array}$ \\
\hline $\begin{array}{l}\text { 23.Types of waste generated during COVID-19 are } \\
\text { Infectious } \\
\text { Non-infectious } \\
\text { Pathological } \\
\text { Radioactive } \\
\text { Chemical } \\
\text { Pharmaceutical }\end{array}$ & $\begin{array}{l}90 \\
36 \\
39 \\
13 \\
28 \\
51\end{array}$ & $\begin{array}{l}35 \% \\
14 \% \\
15 \% \\
5 \% \\
11 \% \\
20 \%\end{array}$ \\
\hline $\begin{array}{l}\text { 24. What ideas do you follow in waste management? } \\
\text { Plan } \\
\text { 3R rule } \\
\text { Committee } \\
\text { Records }\end{array}$ & $\begin{array}{l}72 \\
64 \\
72 \\
49\end{array}$ & $\begin{array}{l}28.1 \% \\
25 \% \\
28.1 \% \\
18.8 \%\end{array}$ \\
\hline $\begin{array}{l}\text { 25.Is there any future precaution to manage waste } \\
\text { planned by your institution? } \\
\text { Yes } \\
\text { No }\end{array}$ & $\begin{array}{l}193 \\
64\end{array}$ & $\begin{array}{l}75 \% \\
25 \%\end{array}$ \\
\hline $\begin{array}{l}\text { 26. Which of this method is followed by your institution for } \\
\text { medical waste treatment? } \\
\text { Thermal } \\
\text { Biological } \\
\text { Irradiation } \\
\text { Mechanical } \\
\text { None of the above }\end{array}$ & $\begin{array}{l}56 \\
93 \\
28 \\
28 \\
52\end{array}$ & $\begin{array}{l}21.9 \% \\
36 \% \\
10.9 \% \\
10.9 \% \\
20.3 \%\end{array}$ \\
\hline $\begin{array}{l}\text { 27. Waste segregation at the source has high risk to waste } \\
\text { handlers } \\
\text { Agree } \\
\text { Disagree }\end{array}$ & $\begin{array}{l}216 \\
41\end{array}$ & $\begin{array}{l}84 \% \\
16 \%\end{array}$ \\
\hline $\begin{array}{l}\text { 28.Used masks (including 3-layer masks, etc.) are disposed } \\
\text { in } \\
\text { Blue bags } \\
\text { Red bags } \\
\text { Yellow bags } \\
\text { Don't know }\end{array}$ & $\begin{array}{l}48 \\
20 \\
169 \\
20\end{array}$ & $\begin{array}{l}18.8 \% \\
7.8 \% \\
65.6 \% \\
7.8 \%\end{array}$ \\
\hline $\begin{array}{l}\text { 29.Do you have sufficient bins in your hospital/institution? } \\
\text { Yes } \\
\text { No }\end{array}$ & $\begin{array}{l}211 \\
46\end{array}$ & $\begin{array}{l}82 \% \\
18 \%\end{array}$ \\
\hline $\begin{array}{l}\text { 30.What is the rating given by you to your } \\
\text { hospital/institution in waste management? } \\
1-3 \\
4-7 \\
8-10\end{array}$ & $\begin{array}{l}20 \\
62 \\
175\end{array}$ & $\begin{array}{l}8 \% \\
24 \% \\
68 \%\end{array}$ \\
\hline
\end{tabular}




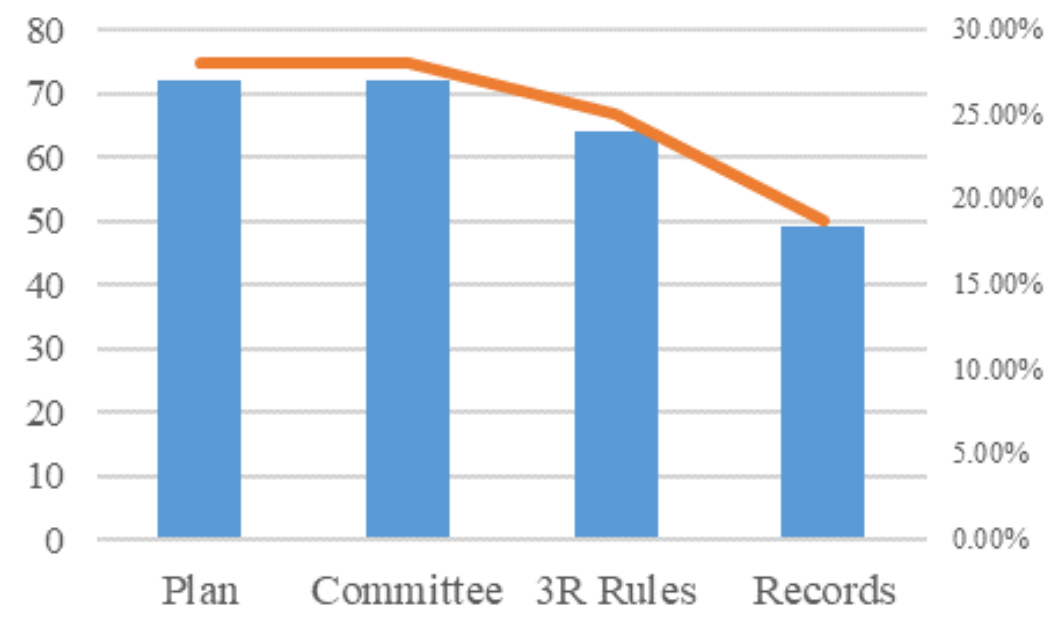

FIGURE 2: TYPE OF WASTE GENERATED DURING COVID 19 PANDEMIC

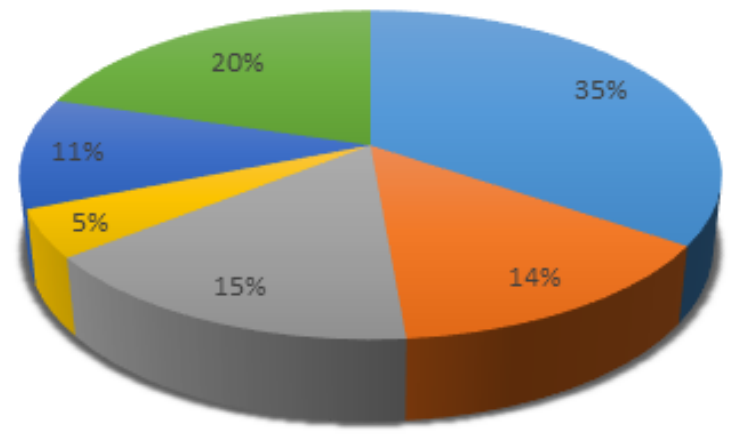

$$
\begin{aligned}
& \text { Infectious } \quad \square \text { Non-infectious } \quad \text { Pathological } \\
& \text { Radioactive } \quad \text { Chemical } \quad \text { Pharmaceutical }
\end{aligned}
$$

FIGURE 3: TYPE OF WASTE OFTEN SEE DURING COVID 19 PANDEMIC

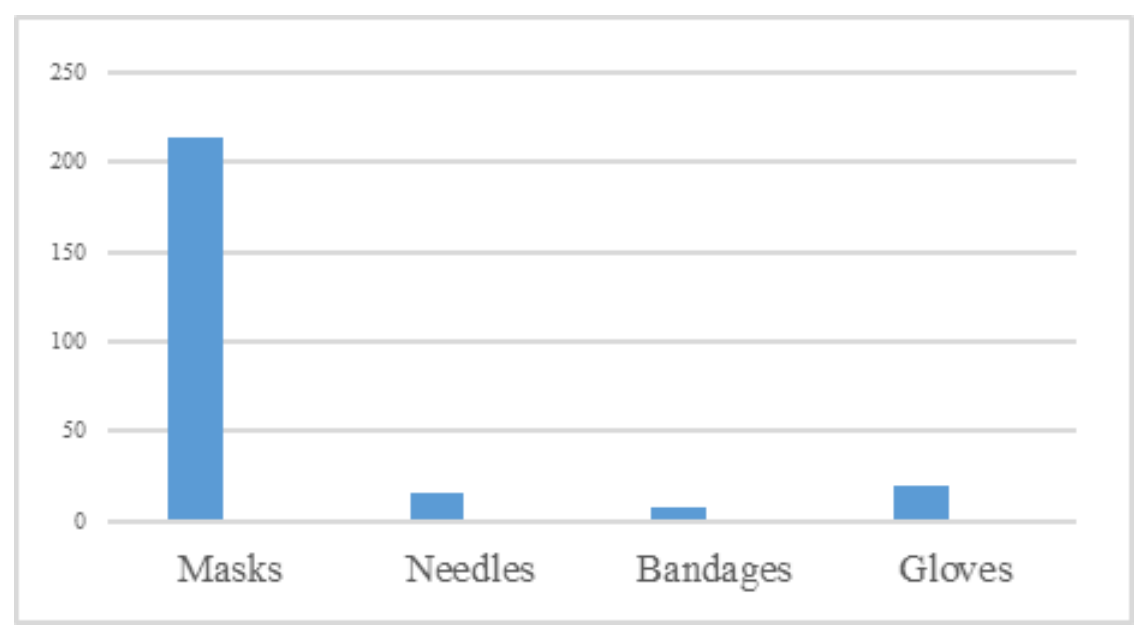

\section{RESULTS}

The waste management procedures in the different hospitals and institutions revealed that $25 \%$ of the facilities

didn't follow all the guidelines suggested by world health organisation and $75 \%$ of the facilities are following all the rules and regulations. A 'bitter truth' is biomedical waste 
production is increasing daily with the increase in number of COVID cases. In our survey about $93.8 \%$ of the respondents agreed that there is a massive increase in biomedical waste generation after COVID-19. Most importantly COVID-19 infected wastes should be collected safely and separately. Almost $89.1 \%$ of the respondents aware that improper waste management cause various health hazards. From the survey it was found that $78.2 \%$ of the respondents answered COVID-19 infected waste is mixed with other common wastes in their hospital. and $10.9 \%$ of the respondents answered they collect covid patient's wastes separately.

It was also found that $28.1 \%$ of the facilities had management plans for handling wastes while $28.1 \%$ of the facilities had a separate management committee to dea the wastes, $25 \%$ of the facilities followed the $3 R$ s rule (Reduce, Reuse, Recycle) of waste management and $18.8 \%$ of the facilities are maintaining daily records of waste generation. $70.3 \%$ of the respondents answered maintaining biomedical waste records are mandatory in their hospital and also found that $71.8 \%$ of respondents have separate biomedical waste disposal policy in their institution/hospital. Almost 35\% considered most of the wastes are infectious, $20 \%$ considered most of the wastes produced are pharmaceutical wastes. Nearly $14 \%$ of the respondents considered as non-infectious and $15 \%$ considered as pathological wastes. Very few respondents considered most of the wastes produced are radioactive wastes. This study also reveals that time of storage before disposal, some of facilities were storing wastes less than 24 hours. On the other hand, $18.8 \%$ of the facilities were having storage time of 48 hours; meanwhile, $15.6 \%$ of the facilities we're storing wastes more than 48 hours. It is found that nearly $50 \%$ of the facilities are using plastic containers for the collection of wastes and $28.1 \%$ of the respondents were using biohazard bags. Only few responded are using meta containers and $82 \%$ of them answered they have sufficient bins in their hospital/institution. Nearly $65.6 \%$ said that nobody in their hospital or institution affected by COVID-19 while handling waste.17.2\% were not aware of such things and $17.2 \%$ said some of the healthcare workers are affected by COVID-19 while handling wastes of COVID infected patients. This shows awareness about personal protective equipment is still needed. When asked about the necessity to improve waste management plan, almost $79.7 \%$ of the respondents answered there is a need to improve waste management technique during the COVID19 pandemic. $12.5 \%$ of respondents answered there is no need and $7.8 \%$ of respondents answered it may be needed. It was found that $40.6 \%$ of hospitals followed incineration techniques for final disposal. Meanwhile, $17.2 \%$ of hospitals buried the wastes on hospitals ground. In addition to this, $42.2 \%$ took the wastes to municipal landfills. For the treatment of waste $36 \%$ of them following biological method. Almost $62.5 \%$ answered that the staff are trained regarding waste collection and $17.2 \%$ of the respondents said no for the above question. About $20.3 \%$ of the respondents don't know whether training is provided or not. When asked about guideline charts displayed near dustbins, $62.5 \%$ answered they have noticed and $37.5 \%$ answered they never noticed such charts. The segregation results showed that $68.8 \%$ of the facilities have separate colour coded bins for collecting COVID patient wastes. The bins used for collection of COVID-19 wastes should be labelled with COVID-19 on it. Almost $56.2 \%$ of the respondents answered the have disposal site at longer distance. When asked about laboratory facilities $68 \%$ of them have clinical/biomedical laboratory, $15.6 \%$ of them have R\&D laboratory, $16.4 \%$ of them have facilities for animal laboratory in their hospital.

One of the most important method in biomedical waste management is source segregation. Waste segregation at the source has high risk to waste handlers and $84 \%$ of the respondents also agreed it. Almost $79.7 \%$ of the respondents answered that they follow colour coding while disposing wastes and $9.4 \%$ agreed they didn't follow colour coding and nearly $10.9 \%$ of the respondents were not aware of colour coding. For the question "How do you dispose used masks?", $65.6 \%$ answered correctly that yellow bags are used. When asked about specific category most of the respondents answered wrongly. For the question "which colour bin is used to dispose glassware and metallic body implants?" only $39.1 \%$ answered correctly and when asked about pathological wastes and contaminated recyclable wastes only $39.1 \%$ and $31.3 \%$ answered correctly. These results clearly show they have lack of knowledge.

Almost $75 \%$ of them answered their institution had future precautionary plans to avoid complication in waste management. From the survey nearly $82.8 \%$ of the respondents considered the use of facemask increased tremendously after COVID-19. Along with facemasks the use of personal protective equipment and testing kid also increased. 


\section{DISCUSSION}

The huge amount of biomedical waste is generated from the isolation wards, emergency clinics and the home quarantine since the outbreak of Novel Corona virus. Based on the survey, the usage of facemask, testing kits, individual protective equipment and nitrile gloves are the main reason for piling up of biomedical waste. [24] A serious and timely collection, treatment, disposal of COVID patient's waste is the major problems by all medical care workers. Based on the survey, $82.8 \%$ considered that at the time of COVID-19 the generation of facemasks increased rapidly. Proper collection and disposal of biomedical waste is crucial for environment safety and may also give a better solution to bio security risk. In this study, it is found that nearly $40.6 \%$ of the facilities are using incineration technique for final disposal of infectious waste which is similar to the study conducted by Mohamed et al where they reported around $40 \%$ of the hospitals in Bahrain followed incineration as final treatment of infectious waste.[25]Meanwhile Another study conducted at Karachi Pakistan showed $70 \%$ of the facilities are following incineration technique.[26] A study by Francis among the nurses in Christian Mission Hospitals at Madurai, Tamilnadu showed that $77 \%$ of the nurses had adequate knowledge and $23 \%$ of the nurses had moderate adequate knowledge about waste management and none of them were not aware of medical waste management.[27]

However, in this study, $62.5 \%$ of the participant's answered staff were trained, which is better than findings from earlier studies from India [28] and even from Ethiopia.[29] On the other hand, a study in Nigerian settings had better results (81\%).[30]

This study reveals that about $35 \%$ of the respondents considered all the healthcare wastes are mostly infectious. The previous study conducted by Sood et al at three dental colleges in Delhi reveals that $60 \%$ of respondents considered all the wastes are hazardous wastes. [31] Similarly, in a study conducted by Aradhya et al in Himachal Pradesh also showed $88.3 \%$ of the respondents considered all the waste are hazardous. [32] But the fact is only $10-15 \%$ of the wastes are hazardous.

It is found that about $79.7 \%$ said they are following colour coding while disposing wastes. But when asked about exact categories only $39.1 \%$ could tell which colour container is used for collecting glassware \& metallic body.
Similarly, very few could tell correct answers for the questions which colour bins are used to dispose infectious and non-infectious wastes. Our study is similar to a study conducted in a tertiary care hospital, Kanchipuram by Mohan Kumar, that also reported only $34.2 \%$ answered correct and the remaining did not answer.[33] But our results are contradicted the result of Kanchi et al in that $86 \%$ of the respondents had knowledge of colour coding.[34] However, a study done by Deo et also found lack of knowledge among the medical staff (20\%).[35] But a study in Davangere city, Karnataka showed $27.2 \%$ were not aware of colour coding. [36]

When coming to record maintenance, $70.3 \%$ considered maintaining records are mandatory. This is similar to a study done by Kanchi et al, who reported $72 \%$. But Mohan Kumar reported $94.8 \%$ considered record maintenance is mandatory. [37] About $89.1 \%$ considered improper waste management cause various health hazards.

When asked about separation of COVID patients wastes $68.8 \%$ of the participants answered they had separate bins for collection. Almost $78.2 \%$ answered one should not mix COVID-19 infected waste with non-infectious waste. Regarding waste management, $79.7 \%$ of the respondents felt improvement is needed to manage wastes during COVID-19 pandemic.

To lessen the volume of PPE and to prevent shortage, it's reuse has been exhorted with legitimate safety measure. [38] N95 masks can be reused for 3-4 times by a similar individual whenever put away in paper packs and kept far from others. [39] The Central Pollution Control Board (CPCB) has made an application called 'COVID19 BWM' for everyday reports on COVID19 waste management and follow-up.[40]

\section{CONCLUSION}

This study showed that creating more awareness among healthcare workers for proper handling, treatment and disposal of medical waste generated from COVID patients is necessary. Creating potential strategies to overcome difficulties while handling and treatment of waste during COVID-19 pandemic may reduce the waste generation and minimize environmental problems. Another important factor from this study is that most of the clinics should follow WHO guidelines on healthcare waste management, during this current pandemic situation, many of institutes followed disposal method like safe pit for COVID waste, and 
incineration was used as a final treatment method by most of the hospitals. Using double layered bags, mandatory labelling and colour coded bins for the management of waste generated during the diagnostics and treatment of suspected and confirmed COVID-19 patients are the guidelines issued by the Central Pollution Control Board (CPCB).

\section{References}

1. Yearender 2020: Stepping into 2021 With Bio-medical Waste Management Lessons From COVID-19 Pandemic Written by: Aastha Ahuja Edited by: Sonia Bhaskar. Available from:

https://swachhindia.ndtv.com/yearender-2020stepping-into-2021-with-bio-medical-wastemanagement-lessons-from-covid-19-pandemic-

$\underline{54763 /}$

2. Ilyas, S., Srivastava, R.R. and Kim, H., 2020. Disinfection technology and strategies for COVID-19 hospital and bio-medical waste management. Science of the Total Environment, 749, p.141652. Available from:

https://www.sciencedirect.com/science/article/abs/ pii/S0048969720351810.

3. US Census Bureau Current Population. Available from: https://www.census.gov/popclock/print.php?compo nent=counter. [Last Accessed on 25 September 2020]

4. Worldometer. Coronavirus cases. Available from: https://www.worldometers.info/coronavirus/ [Last accessed on 9 November 2020]

5. Chand, S., Shastry, C.S., Hiremath, S., Joel, J.J., Krishnabhat, C.H. and Mateti, U.V., 2021. Updates on biomedical waste management during COVID-19: The Indian scenario. Clinical Epidemiology and Global Health, p.100715. Available from:

https://reader.elsevier.com/reader/sd/pii/s221339842 1000191 ? token $=4$ D08414CC5F456C1402D2ACEC87DD 58A414C5993669ED52B18A9F0522343E12842A01095F02 D60FCF0C25F3C5A6D2D2D.

6. Central pollution control board. Annual report 2017/2018. Ministry of environment, forest, and climate change. 2018: 1-153. Available from https://cpcl.nic.in/openpdffile.php?id=UmVwb3JORm IsZXMvOTIYXZE1NiQwMzg5OTFf

WVkaWFwaG90bzEOMjg2LnBkZg== [Accessed on 9 November 2020].

7. Central pollution control board. Annual report 2018/2019. Ministry of environment, forest, and climate change. 2019: 1-160. Available from: https://cpcb.nic.in/openpdffile.php?id=UmVwb3JORm
IsZXMvMTEXOV8XNTk3MDM3NTM0X21|IZGlhcGhvdG8xO TY1Ni5WZGY $=$ [Accessed on 9 November 2020].

8. Chartier, Y., Safe management of wastes from healthcare activities. 2014: World Health Organization.

9. Arshad, N., et al., Hospital waste disposal: a review article. Journal of Pharmaceutical Sciences and Research, $2011.3(8)$ : p. 1412.

10. Asante, B., E. Yanful, and B. Yaokumah, Healthcare Waste Management; Its Impact: A Case Study of The Greater Accra Region, Ghana. International Journal of Scientific \& Technology Research, 2014. 3(3).

11. Li, C.-S. and F.-T. Jenq, Physical and chemical composition of hospital waste. Infection Control \& Hospital Epidemiology, 1993. 14(3): p. 145-150.

12. Raju, M.L. and K.S. Rao, Urban Ecology and Environment Pollution: A Comparative Study Of Waste Management Practices In Visakhapatnam City And Vizianagaram Town In India. Applied water science. 7: p.1497-1504.

13. Qasmi, S.A. and B.A. Khan, Review of biological waste management in research, biomedical, and veterinary laboratories in Karachi, Pakistan. Journal of Biosafety and Biosecurity, 2019. 1(2): p. 100-104.

14. Bazrafshan, E. and F. Kord Mostafapoor, Survey of medical waste characterization and management in Iran: a case study of Sistan and Baluchestan Province. Waste Management \& Research, 2011. 29(4): p. 442450.

15. Tiwari, A.V. and P.A. Kadu, Biomedical waste management practices in India-a review. International Journal of Current Engineering and Technology, 2013. 3(5): p. 2030-4.

16. Nzediegwu, C. and S.X. Chang, Improper solid waste management increases potential for COVID-19 spread in developing countries. Resources, conservation, and recycling, 2020. 161: p. 104947.

17. Sharma, S.K. and S. Gupta, Healthcare waste management scenario: A case of Himachal Pradesh (India). Clinical Epidemiology and Global Health, 2017. 5(4): p. 169-172.

18. Sangkham, S., Face mask and medical waste disposal during the novel COVID-19 pandemic in Asia. Case Studies in Chemical and Environmental Engineering, 2020. 2: p. 100052.

19. Ramteke, S. and B.L. Sahu, Novel coronavirus disease 2019 (COVID-19) pandemic: considerations for the biomedical waste sector in India. Case Studies in Chemical and Environmental Engineering, 2020. 2: p. 100029. 
20. Verma, L.K., et al., Biomedical waste management in nursing homes and smaller hospitals in Delhi. Waste Management, 2008. 28(12): p. 2723-2734.

21. Golandaj, J.A. and K.G. Kallihal, Awareness, attitude and practises of biomedical waste management amongst public health-care staff in Karnataka, India. Journal of Humanities and Applied Social Sciences, 2020.

22. Scudellari, M., How the pandemic might play out in 2021 and beyond. Nature, 2020: p. 22-25.

23. Emerging respiratory viruses, including COVID 19: methods for detection, prevention, response and control. Open WHO. Available https://open who.org/courses/introduction to ncov

24. Yadavannavar, M., A.S. Berad, and P. Jagirdar, Biomedical waste management: A study of knowledge, attitude, and practices in a tertiary health care institution in Bijapur. Indian journal of community medicine: official publication of Indian Association of Preventive \& Social Medicine, 2010. 35(1): p. 170.

25. Manupati, V.K., et al., Selection of the best healthcare waste disposal techniques during and post COVID-19 pandemic era. Journal of Cleaner Production, 2021. 281: p. 125175.

26. Sood, A.G. and A. Sood, Dental perspective on biomedical waste and mercury management: a knowledge, attitude, and practice survey. Indian Journal of Dental Research, 2011. 22(3): p. 371.

27. Francis, L., A Descriptive Study to Evaluate the level of Knowledge regarding Biomedical Waste Management among Nurses in Christian Mission Hospitals at Madurai. Asian Journal of Nursing Education and Research, 2018. 8(3): p. 335-338.

28. Ismail, I.M., et al., Knowledge, attitude and practice about bio-medical waste management among personnel of a tertiary health care institute in Dakshina Kannada, Karnataka. Al Ameen J Med Sci, 2013. 6(4): p. 376-80.

29. Deress, T., et al., Knowledge, attitude, and practice of waste handlers about medical waste management in Debre Markos town healthcare facilities, northwest Ethiopia. BMC research notes, 2019. 12(1): p. 1-7.

30. Golandaj, J.A. and K.G. Kallihal, Awareness, attitude and practises of biomedical waste management amongst public health-care staff in Karnataka, India. Journal of Humanities and Applied Social Sciences, 2020.

31. Abrol, A., et al., Awareness and practices regarding biomedical waste management among health care workers in a tertiary care hospital in Himachal Pradesh.
Indian Journal of Microbiology Research, 2019. 6(1): p. 92-96.

32. Mohamed, L., S. Ebrahim, and A. Al-Thukair, Hazardous healthcare waste management in the Kingdom of Bahrain. Waste management, 2009. 29(8): p. 24042409.

33. Kumar, M., Knowledge, attitude and practice study on bio-medical waste management among interns in a tertiary care hospital in Kancheepuram, Tamil Nadu. Int J Community Med Public Health, 2016. 6(8): p. 33543357.

34. Padmaja, K., Knowledge, attitude, practice regarding hospital waste management among interns \& nurses of tertiary care hospitals of Navi Mumbai. Sch J Appl Med Sci, 2017. 5: p. 526-530.

35. Deo, D., S. Tak, and S. Munde, A study of knowledge regarding biomedical waste management among employees of a teaching hospital in rural area. $J$ of ISHWM, 2006. 1: p. 12-16.

36. Sudhir, K., et al., Awareness and practices about dental health care waste management among dentists of Davanagere city, Karnataka. Journal of Indian Association of Public Health Dentistry,2006. 4(8): p. 44.

37. Ilyas, S., R.R. Srivastava, and H. Kim, Disinfection technology and strategies for COVID-19 hospital and bio-medical waste management. Science of the Total Environment, 2020. 749: p. 141652.

38. MOHFW India Advisory on re-processing and re-use of eye-protection - Goggles Published on May 27, 2020.Available at

https://www.mohfw.gov.in/pdf/Advisoryonreprocessin gandreuseofeyeprotectiongoggles.pdf.

39. Recommended guidance for extended use and limited reuse of N95 filtering facepiece respirators in healthcare settings available at https://www.cdc.gov/niosh/topics/hcwcontrols/reco mmendedguidanceextuse.html.

40. MOEF\&amp; FF: Central Pollution Control Board. (Revision 4) Guidelines for Handling, Treatment and Disposal of Waste Generated during Treatment/Diagnosis/ Quarantine of COVID-19 Patients. https://cpcb.nic.in/uploads/Projects/BioMedical-Waste/BMW-GUIDELINES-COVID 19. 